Radio Drama 


\section{Radio Drama}

Ian Rodger

M 
(C) Ian Rodger 1982

All rights reserved. No part of this publication may be reproduced or transmitted, in any form or by any means, without permission.

First published 1982 by

THE MACMILLAN PRESS LTD

London and Basingstoke

Companies and representatives throughout the world

ISBN 978-0-333-29429-1 ISBN 978-1-349-16647-3 (eBook)

DOI 10.1007/978-1-349-16647-3

The paperback edition of this book is sold subject to the condition that it shall not, by way of trade or otherwise, be lent, resold, hired out, or otherwise circulated without the publisher's prior consent in any form of binding or cover other than that in which it is published and without a similar condition including this condition being imposed on the subsequent purchaser. 


\section{Contents}

$\begin{array}{ll}\text { Preface } & 0\end{array}$

1 National Responses to Radio 1

2 The Conflict between Theatre and Radio 11

3 The Need for Narration $\quad 27$

4 The Revolution in Diction 39

5 The National Theatre $\quad 54$

6 The Arrival of the Poets 69

7 The Influence of Features $\quad 86$

8 The Discovery of Silence $\quad 97$

9 The Drama School 109

10 The Radio Shape 123

11 Technical Advances

12 Conclusions 147

$\begin{array}{ll}\text { Notes and References } & 158\end{array}$

$\begin{array}{ll}\text { Bibliography } & 161\end{array}$

$\begin{array}{ll}\text { Index } & 163\end{array}$ 


\section{List of Plates}

1 Val Gielgud and Lance Sieveking in 1930

2(a) Louis MacNeice in 1946

(b) D. G. Bridson in 1949

3 Francis Dillon in 1947

4 Tyrone Guthrie in 1950

5 Laurence Gilliam in 1953

6(a) The BBC Radiophonic Workshop in 1958

(b) The studio control room in 1979

7(a) Oliver Twist on radio in 1952

(b) The Daedalus Dimension in 1978

8 Donald McWhinnie and Samuel Beckett

\section{Acknowledgements}

Plates $1,2(b), 3,5,6(a), 6(b), 7(a)$ and $7(b)$ are reproduced by permission of the BBC Photographic Library. Plates 2(a) and 4 are reproduced by permission of the BBC Hulton Picture Library.

Every attempt has been made to trace copyright holders. The publishers would be willing to make the necessary arrangements in cases where it has not been possible to make an acknowledgement. 


\section{Preface}

I was one of radio's children. Before I could read, my grandmother clapped some headphones to my ears so that I could hear, amidst the crackling atmospherics, the magic of a distant voice speaking to me. Later, when I was of school age, the BBC's Children's Hour became an imperative daily ritual, bringing to me among other things the plays of L. du Garde Peach who made the past history of my country alive and immediate. When I had measles, my father carried the imitation-mahogany radio set into my bedroom so that I could hear the marvel of D. G. Bridson's Coronation Scot. The radio set had knobs by this time and I used to twiddle them to catch Radio Luxembourg and all the languages of Europe. When I was eleven, I tuned in accidentally to a speech by Hitler and, though I could not understand German, the voice conveyed to me a message of terror which my elders, who were mostly newspaper readers and not radio fanatics, found hard to appreciate. When the war came, I tuned into Warsaw and knew when the station went off the air that Poland had fallen. In Sussex during the Battle of Britain, I listened on a short wave receiver to a German pilot crying out 'Achtung, Spitfire!' as he flew only a few thousand feet above me. Such moments brought home radio's immediacy but it was the journeys of the imagination encouraged by the works of people like Francis Dillon, Douglas Cleverdon and Louis MacNeice which shaped and directed my adolescent mind during the war.

Like many writers of my generation it was inevitable that I should choose radio as one of my means of communication. I gave my first radio talk for the English service of Sveriges Radio and my first radio play was produced in Dutch by AVRO, Hilversum. I am grateful to Sweden and Holland for giving me 
my first chance of a radio audience but I am naturally more indebted to the British producers who later took my work in hand and began to teach me the crafts of radio. I am grateful in particular to David Thomson, Francis Dillon, John Gibson, Terence Tiller, Robin Midgley, John Tydeman, Richard Imison, Alfred Bradley, Tony Cliff and Robert Cooper. I also had the luck to be the radio drama critic of the Listener during a time when something of a dramatic renaissance occurred in Britain. In the course of researching material for this book I am grateful for the help and assistance given to me by the BBC Written Archives Centre. I would also like to thank Michael Bakewell, Eric Ewens, Rene Cutforth, Douglas Cleverdon, Geoffrey Bridson, Francis Dillon and Michael Barsley for their verbal accounts of their life and times at the BBC. I wish to thank Mrs Linklater for permission to quote from Eric Linklater's The Cornerstones, Mrs Butler for allowing me to quote from the writings of Tyrone Guthrie and Faber and Faber Ltd, for allowing quotations from the writings of Louis MacNeice. I also wish to thank the Sieveking family for allowing quotations from Lancelot Sieveking's unpublished memoirs, and to thank Val Gielgud, Donald McWhinnie, W. M. S. Russell, Frances Gray, Eckhard Breitinger, Horst Priestnitz, Rudiger Imhof, John Gielgud and John Braidwood for permission to quote from their works. I am also grateful to the Arts Council of Great Britain for providing me with financial support in the research and writing of this book. 